\title{
GRAmmaticalization AND LeXICALIZATION: SUggeStions Regarding the Development of the Chinese Change-of-state Verb
}

\author{
LI Wenchao \\ University of Zhejiang, China \\ widelia@zju.edu.cn
}

\begin{abstract}
This paper discusses the evolution of the Chinese verb 断 (duàn 'break'), exploring how the lexicon has transformed from being a substantive transitive verb in the past to the various functions it fulfils in contemporary Chinese: i.e. a resultative complement, an adjective, an adverb and a noun. Findings reveal that duàn was initially transitive and its intransitive function was derived during the Spring and Autumn period (772-476 BC). The two functions co-existed for the rest of the Pre-Qin period (before $221 \mathrm{BC}$ ). Duàn's transition into a resultative complement began during the Eastern Han dynasty (AD 25-220), and its noun function was shaped in the Warring State period (475-221 $\mathrm{BC}$ ). Finally, Duàn's adjective and adverb functions are noted to begin in Middle Chinese (AD 420-1279). Although some of these transitions took place more or less simultaneously during overlapping periods, they developed via two separate paths: the process by which duàn developed into a resultative complement, an adverb, and an adjective is that of grammaticalization, while on the other hand, the process by which duàn developed into a noun is that of lexicalization. Essentially, it is the intransitive function that is subject to grammaticalization and it is the transitive function that is subject to lexicalization. In this paper it is therefore proposed that the above diachronic change is taken as a cline, and is put forward as follows: (a) grammaticalization and lexicalization are not distinct processes but rather happen to a lexeme more or less simultaneously; and (b) interrelationship between the two processes is orthogonal.
\end{abstract}

Keywords: grammaticalization; lexicalization; diachronic approach; Chinese

\section{Povzetek}

Članek razpravlja o razvoju kitajskega glagola 'zlomiti' 断 duàn in razvoju njegovih funkcij skozi čas. Medtem ko je najprej deloval le kot prehodni glagol, se lahko v sodobni kitajščini pojavlja kot rezultativno dopolnilo, pridevnik, prislov in celo kot samostalnik. Rezultati raziskave kažejo, da je prvotno prehodni glagol svojo neprehodno vlogo dobil v obdobju Pomladi in jeseni (772-476 pr.n.št.). Ti dve vlogi je vzporedno obdržal vse do obdobja Qin (221 pr.n.št.). Njegova preobrazba v rezultatsko dopolnilo se je pričela v obdobju Dinastije Vzhodni Han, še pred tem se je oblikovala tudi njegova samostalniška vloga (obdobje Vojskujočih se držav, 475-221 pr.n.št.). Njegovi najnovejši dve vlogi, tj. pridevniška in prislovna, sta se začeli pojavljati v srednji kitajščini (420-1279). Kljub temu, da so se nekateri izmed teh prehodov zgodili bolj ali manj vzporedno, je bila njihova pot sprememb precej različna; proces, preko katerega se je glagol 'zlomiti' 断 duàn izpopolnil v rezultatsko dopolnilo, pridevnik in prislov, je slovnični (gramatikalizacija), medtem ko je proces njegovega razvoja $v$

Acta Linguistica Asiatica, 8(2), 2018.

ISSN: 2232-3317, http://revije.ff.uni-lj.si/ala/

DOI: 10.4312/ala.8.2.111-137 
samostalnik leksikalni (leksikalizacija). Poleg tega smo prišli do ugotovitev, da je slovnični proces sprožil neprehodni glagol 'zlomiti' 断 duàn, njegova prehodna različica pa je bila osnova leksikalizaciji. $\checkmark$ članku predlagamo, da omenjeno spremembo skozi čas dojemamo kot skalarno spremembo, ki jo zaznamujeta naslednji dve značilnosti: (a) gramatikalizacija in leksikalizacija se pojavljata istočasno in nista povsem neodvisna procesa ter (b) odnos med procesoma je ortogonalen.

Ključne besede: gramatikalizacija; leksikalizacija; diahroni pristop; kitajščina

\section{Introduction}

Chinese vocabulary has undergone a lengthy evolution. In the Pre-Qin period, the Chinese language consisted of monosyllabic roots, to which affixes were attached (Sagart, 1999). During the Early Han dynasty, disyllabic word roots occurred, with verb

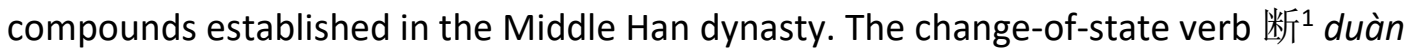
'break' is a typical instance. In contemporary Chinese, duàn is usually used as a resultative complement. It forms syntactic verb compounds (V-V) with action verbs such as 切 qie 'cut', 剪 jiăn 'cut', etc. (1) provides an illustration of V-V 切断 qiē-duàn 'cut-broken'.

(1) Resultative complement
a. 张三
切断
了电源。
(Transitive)
Zhāng-sān qiē-duàn le
diàn-yuán.
Zhangsan cut-off PERF power
'Zhangsan cut off the power.'
b. 电源切断了。
Diàn-yuán qiē-duàn le.
power cut-off PERF
'The power was cut off.'

In (1), duàn is a resultative complement. The V-V form 切断 qiē-duàn 'cut-broken' can be either transitive or intransitive. About 3,000 years ago duàn was a substantive transitive verb, meaning 'to cut/break'. Although semantically duàn in (1) still retains the original meaning, i.e. 'broken', syntactically it no longer bears the initial function, i.e. that of a transitive verb.

Another illustration comes from 打断 dă-duàn 'hit-broken', but this presents a different picture. 打断 dă-duàn can have two meanings. The first meaning is 'hitbroken', where 打 dă is an action verb and duàn a resultative complement (such use resembles 切断 qiē-duàn 'cut-broken' in (1)). The second meaning of 打断 dă-duàn is 'to interrupt'. More interestingly, when 打断 dă-duàn has the first meaning, i.e. 'hitbroken', it may either be transitive (e.g. 打断了树枝 dă-duàn le shù-zhī 'The branch

\footnotetext{
${ }^{1}$ Throughout the paper, the discussions use the simplified Chinese character (e.g. 断) while the illustrations use the traditional Chinese characters (e.g. 斷).
} 
was hit and it broke.') or intransitive (e.g. 树枝打断了 shù-zhī dă-duàn le 'The branch broke'). However, when 打断 dă-duàn has the second meaning, i.e. 'to interrupt', it only bears transitivity, as shown in (2):

(2) a. 打断谈话 dă-duàn tán-huà 'interrupt the discussion'

b. *谈话打断 tán-huà dă-duàn 'the discussion interrupts'

The ill-formed (2b) can be improved by turning the sentence into a passive voice, thus (2b) becomes 谈话被打断了 tán-huà bèi dă-duàn le 'the discussion was interrupted. ${ }^{2}$

This having been said, we can not say that duàn has absolutely lost its substantive function. In the following compound nouns, duàn retains the transitive function:

(3) Transitive use in compound verbs

a. 断水 duàn-shuǐ 'water break'

b. 断电 duàn-diàn 'power off'

c. 断粮 duàn-liáng 'run out of food'

d. 断炊 duàn-chuĩ 'run out of rice and fuel'

e. 断档 duàn-dàng 'out of stock'

f. 断种 duàn-zhǒng 'heirless'

The objects of duàn in this respect are limited to 水 shuǐ 'water', 电 diàn 'electricity', 种 zhǒng 'heir', etc. The following compound nouns shows a more idiomaticised 断 duàn:

(4) Transitive use in compound nouns

a. 断头台 duàn-tóu-tái 'cut-head-platform (scaffold)'

b. 粘滞性断裂 zhān zhì xìng duàn liè 'glutinous fracture'

Duàn also plays a role as an adjective, which is exemplified by (5).

(5) Adjectival use in compounds

a. 断枝 duàn-zhī 'broken-branch'

b. 断绳 duàn-shéng 'broken-string'

One may argue that a verb may modify a noun, and is as such translated into English with an adjective or a past participle. A representative example is duàn-zhi (break-branch) 'broken branch' (5a), however, but this does not yet prove that Chinese 断 duàn is to be analysed as an adjective.

Trying to eliminate the impossible roles, we can first say that in duàn-zhī (5a), 断 duàn can not be analysed as a verb. There are two reasons for it. The first reason is that the NP duàn-zhī (break-branch) is composed by duàn + a noun (zhī (branch). If duàn was an intransitive verb, the word order would have to be a noun (branch) + duàn.

\footnotetext{
2 被 bèi is an auxiliary verb, denoting the passive voice.
} 
Furthermore, to function as a transitive verb, duàn must appear with a light verb 弄 nòng or 打 dă, which correspond to the verb do in English and する suru in Japanese.

$\begin{array}{clll}\text { (5) a'. 开断 } & \text { 了 } & \text { 树枝 } \\ \text { nòng duàn } & \text { le } & \text { shù-zhī } \\ \text { do-break } & \text { PERF } & \text { branch } \\ \text { a." } & \text { 打断 } & 了 & \text { 树枝 } \\ \text { dă duàn } & \text { le } & \text { shù-zhī } \\ \text { do-break } & \text { PERF } & \text { branch }\end{array}$

The second reason is that when a verb modifies a noun, the verb duàn must either be in the past participle form or, an aspect marker gets necessary. See the example below.

(5) a"'”. 断 了 的 枝

duàn le de zhī

broken PERF NOM branch

'the branch that was broken'.

(的 is a nominalizer)

With this in mind, it is reasonable to deem 断 duàn as an adjective. Another similar example is 断椅 duàn yǐ (broken-chair).

However, example (6) shows that duàn can also function as an adverb.

(6) Adverbial use in compound nouns/verbs ${ }^{3}$ or phrases

a. 断言 duàn-yán 'absolutely assert'

b. 断定 duàn-dìng 'absolutely judge'

c. 断不能相信 duàn bú néng xiàng xìn 'absolutely unreliable'

d. 断不能接受 duàn bú néng jiē shòu 'absolutely unacceptable'

In the corpus of contemporary Chinese ${ }^{4}$, there are 199,742 tokens of contemporary duàn. We took 800 tokens at random, and found the following distribution of different functions ${ }^{5}$.

\footnotetext{
${ }^{3}$ Due to the lack of morphological marker, the Chinese category is hard to identify. It seems that 断 言 duàn-yán 'absolutely assert' and 断定 duàn-dìng 'absolutely judge' can be a compound noun or a compound verb according to different syntactic environments.

${ }^{4}$ The corpus of Modern Chinese (http://ccl.pku.edu.cn/) is constructed by the Center for Chinese Linguistics at Beijing University.

${ }^{5}$ Duàn's noun use is mostly seen in Old and Middle Chinese. It appears to have declined in Modern Chinese.
} 
Table 1: Function distribution of duan in The corpus of Modern Chinese (sample)

\begin{tabular}{lcc}
\hline Category & Type & Token \\
\hline Transitive verb & 20 & 93 \\
Intransitive verb & 15 & 175 \\
Adjective & 10 & 89 \\
Adverb & 9 & 76 \\
Resultative complement & 21 & 210 \\
\hline
\end{tabular}

The functions that 断 duàn presents in contemporary Chinese significantly differ from those it fulfilled 3,000 years ago. In Odes (1046-771 BC, Western Zhou dynasty), 断 duàn is a substantive transitive verb, meaning 'cut/break'. We detected three tokens of the transitive use in the Odes, eight tokens in the Book of Change (1046 BC-771 BC, West Zhou dynasty) and three tokens in The Classic of History (772-476 BC, Spring and Autumn). Illustrations are provided in (7)-(8).

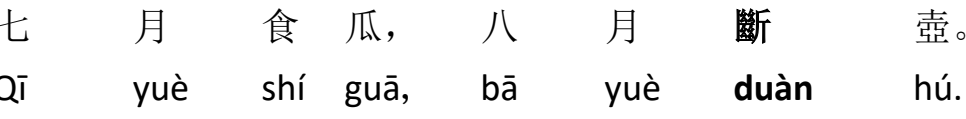

Seventh month eat melon, eighth month cut.down bottle-gourd 'In the seventh month, they eat the melons; and in the eighth, they cut down the bottle-gourds.'

(Odes)
(8) 繫辭焉, 以 斷 其 吉凶。 Jì cí yān, yǐ duàn qí jí-xiōng.

Append explanation PART PREP determine PART good evil 'He then appended his explanation (to each line of the diagrams), to determine the good or evil indicated by it.'

(Book of Change)

This study explores the evolution of the Chinese verb 断 duàn in an effort to understand how it has transformed from a substantive transitive verb to the various forms it takes in contemporary Chinese: i.e. a resultative complement, an adjective and an adverb.

Categorisation of the development of the Chinese language basically follows the insights suggested by the linguist Karlgren (1918):

(a) Old Chinese: Shang dynasty, Zhou dynasty, Spring and Autumn and Warring State period (1200 BC-221 BC);

(b) Pre-Middle Chinese: Qin dynasty and Han dynasty (221 BC to AD 220);

(c) Middle Chinese: Southern and Northern dynasties (AD 420-589), Sui, Tang (AD 618-907), Song dynasties (AD 220-1279); and

(d) Pre-Modern Chinese: Yuan, Ming and Qing dynasties (AD 1271-1912). 
The data are predominantly drawn from the Chinese Text Project corpus (http://ctext.org/). The scope of the investigation of Old Chinese is confined to the period BC 1200 to the first few centuries AD. The Pre-Qin period is relatively long and therefore the number oftargeted sources for this period is higher than that for the other two periods. A list of documents used in the study is provided at the end of the article.

This paper is organised as follows: Section 1 gives a brief introduction to the various functions of duàn in contemporary Chinese. Section 2 touches upon two concepts that are relevant to this study, i.e. grammaticalization and lexicalization. Section 3 explores the function of duàn in Old Chinese. Section 4 focuses on Pre-Middle and Middle Chinese, and Section 5 on Pre-Modern Chinese. Section 6 highlights the results and further addresses theoretical implications of this study.

\section{Grammaticalization and lexicalization}

The central point of this study is to uncover how duàn moved from functioning as a transitive verb in Old Chinese to functioning as a resultative complement, an adverb, and an adjective in contemporary Chinese. This obliges us to touch upon some general issues regarding the concepts of grammaticalization and lexicalization.

Grammaticalization deals with the question of how a lexical item develops into a marker of a grammatical category or how a marker representing a less grammatical function takes on a more grammatical one (Kuryłowicz, 1965, Bisang, 2011). The concept grammaticalization was first put forward by Zhou Boqi, a Chinese scholar of the Yuan dynasty (1279-1368). He stated: 'Today's function words are all former full words (今之虚字皆古之實字 jīn-zhī-xū-zì-jiē-gǔ-zhī shí-zi)'. Such a process was known as 'voiding (虚化 xūhuà)'. About 500 years after Zhou Boqi, German linguist Bopp (1816, 1833) conducted a pioneering study on grammaticalization evolution, with a particular focus on the affixes of Germanic languages. The boom of modern studies of grammaticalization was inspired by the publications of Givón $(1971,1979)$. The point of departure for cross-linguistic studies is Givón's note that 'today's morphology is yesterday's syntax'. Later on, Christian Lehmann (1982) established a milestone with his publication Thoughts on Grammaticalization. Since then, grammaticalization has been studied intensively in different linguistic fields (Narrog and Heine 2011) such as e.g. functional linguistics (Croft, 2000, Harder \& Boye, 2011), cognitive grammar (Langacker, 1987, 1991, 2011), pragmatics (Traugott, 2002), construction grammar (Trousdale, 2008, Gisborne \& Patten, 2011), language acquisition (Diessel, 2011) and social linguistics (Nevalainen \& Palander-Collin, 2011).

The definition of grammaticalization has been revised. In earlier times, focusing only on lexicons was most common. One classical definition comes from Kurylowiczs (1965, p. 69), according to whom, grammaticalization consists of increasing the range 
of a morpheme from a lexical to a grammatical (or from a less grammatical to a more grammatical) status. For instance, the English will was originally a substantive verb, meaning 'want', but was grammaticalized as an auxiliary verb, expressing the future of 'to be' (Himmelmann, 2004). Traugott and Heine (1991) argue that, when discussing how substantive lexicons move into function words, the important factor of construction can not be neglected, as the development of grammatical items is shaped by the constructions in which these items occur. Therefore, they refine grammaticalization as 'the development of constructions [...] via discourse practices into more grammatical material', e.g. lexical items transit into morphological formatives. This view was welcomed by many linguists, including Bybee, Perkins, Pagliuca, Lehmann, and Himmelmann. Bybee, Perkins and Pagliuca (1994, p. 4) demonstrate that the entire construction (not simply the lexical meaning of the stem) is the precursor, and hence the source, of the grammatical meaning. Lehmann (1992, p. 406) notes that lexical items alone do not grammaticalize. They do so only in specific contexts. Himmelmann (2004, p. 31) contends that 'it is the grammaticizing element in its syntagmatic context which is grammaticized'. Most crucially, grammaticalization involves a number of correlated changes, which leads to another concept: lexicalization.

Lexicalization is considered to require the following conditions: phonetic reduction, morphological demotivation, and the loss of semantic compositionality. Himmelmann's (2004) account of lexicalization is introduced below.

Lexicalization represents:

(a) creating a new lexeme out of two or more existing ones, which may continue to exist independently, e.g. collocations.

(b) creating a formative that can be used productively for the formation of new lexemes, e.g. compounds, inflectional formatives;

(c) deriving a new lexeme from a single existing one, which may continue to exist independently, e.g. individual lexical items, grammatical formatives; and

(d) patterns of semantic features that are systematically encoded in the lexicon, e.g. semantic/cognitive features.

Himmelmann's (2004) account of lexicalization is elegant, but handling 'compounds' as a result of lexicalization appears problematic. Take Chinese verb compounds $(\mathrm{V}-\mathrm{V})$ for instance. The predicate-complement type of Chinese $\mathrm{V}-\mathrm{V}$ consists of an action $\mathrm{V} 1+$ a resultative complement V2. Crucially, V2 was originally a substantive change-of-state verb that was grammaticalized into a complement. Grammaticalization is also seen in the V-V motion, where the second constituents, i.e. directional complements, are derived from substantive motion verbs.

Due to the lack of morphological change, it is difficult to tackle the issue where the function of duàn is transferred via grammaticalization manipulation, and which comes from lexicalization device. This study assumes that duàn's various functions develop via 
two separate paths. The process by which duàn developed into a resultative complement, an adverb, and an adjective is the case of grammaticalization, while the process by which duàn developed into a noun is the case of lexicalization.

Another issue is the interrelationship between grammaticalization and lexicalization in case of duàn, given the co-occurrence of multiple transitions. Regarding this interrelationship, previous research falls into two main streams. One such stream conceives the two processes as a constant change leading from lexicalization to grammaticalization and the other way around (Himmelmann, 2004). The other stream deems the two processes to be opposite (Heine, 1993); in other words, lexicalization is the reverse process of grammaticalization (Kuryłowicz, 1965). Alternatively, the two processes are in an orthogonal or parallel relationship (Himmelmann, 2004). This study introduces data from Chinese, in particular the change-of-state verb duàn. It explores how the verb is grammaticalized and lexicalized, and how the two processes relate.

In addition, it is hypothessed that the change always happens in the direction content words to empty words, from lexical items to grammatical elements, or from less grammatical to more grammatical, and never in the opposite direction. This leads to the assumption that grammaticalization is unidirectional. In language evolution, Heine and Kuteva (2007) claim that nouns are transformed regularly into adverbs, yet the reverse is exceedingly uncommon. Incorporating this insight, they produce an 'evolutionary network', which describes the developmental layers of commonly recognised grammatical categories, c.f. Figure 1.

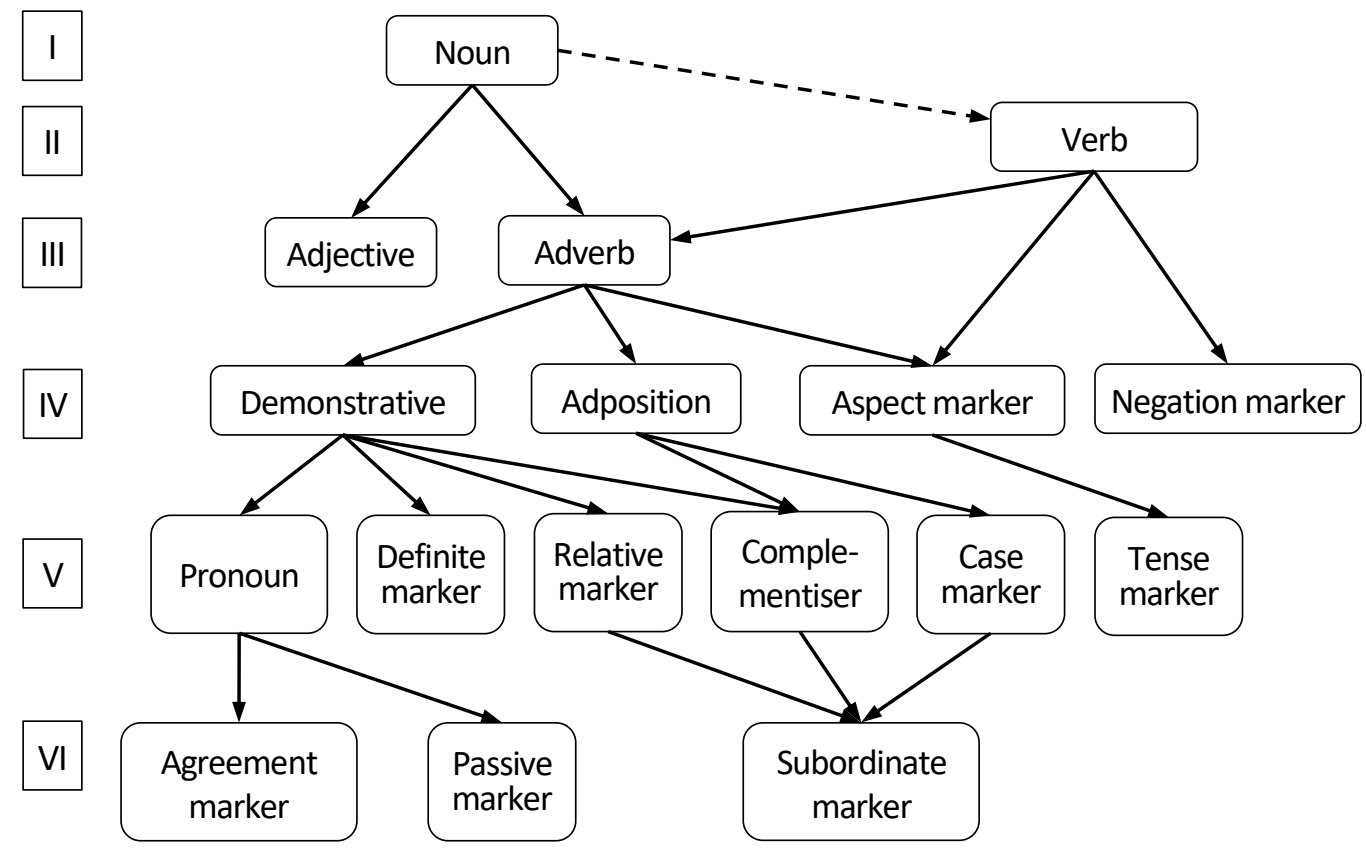

Figure 1: Layers of grammatical evolution via pathways of grammaticalization (Heine \& Kuteva, 2007, p. 111) 
This view, however, is challenged by scholars such as Newmeyer (1998) and Norde (2001). Consequently, another concept, 'degrammaticalization', has been posited. Degrammaticalization refers to a change from a grammatical element to a lexical item, or from a more grammatical element to a less grammatical one. This study makes a further step forward in investigating whether the transformation of the multiple functions of duàn is unidirectional or reversible.

\section{3 断 duàn in Old Chinese}

We begin by looking at the function of 断 duàn in Old Chinese.

\section{1 断 duàn as transitive verb}

In the Pre-Qin period (before $221 \mathrm{BC}$ ), 断 duàn is mostly employed for its transitivity. The following illustration comes from 詩經 Odes (1046 BC-771 BC, Western Zhou dynasty):

$\begin{array}{llll}\text { (9) 是 } & \text { 斷 } & \text { 是 } & \text { 度。 } \\ \text { Shì duàn } & \text { shì dù. }\end{array}$

PRON cut.down, PRON convey

'We cut them down, and conveyed them here.'

(Odes)

是 shì is a pronoun, denoting 'this/them', followed by the transitive verb 断 duàn. This SOV word order is not unfamiliar in Old Chinese and somewhat resembles Modern Japanese, which is alleged to be an Altaic language.

The following illustration comes from 莊子 Zhuang Zi (350 BC - 250 BC), completed in the Warring State period, 500-600 years after the Western Zhou dynasty:

(10) 越人斷髮文 身。 Yuè rén duàn fà wén shēn.

Yue people cut hair tattoo body

'The people of Yue cut their hair and tattooed their bodies.'

(Zhuang Zi)

断 duàn is employed in a transitive way, taking 髮 fà 'hair' as its object. The option of itstransitive role is further detected (eight tokens) in Xun Zi (Warring State: 475 BC$221 \mathrm{BC}), 14$ tokens in Mo Zi (Spring and Autumn - Warring State).

\section{2 断 as intransitive verb}

The following is from 尚书 The Classic of History (Spring and Autumn period: 772-476 $\mathrm{BC})$, where 断 duàn functions as an intransitive verb. Intriguingly, 断 duàn here denotes a metaphorical meaning, i.e. 'make decision': 
$\begin{array}{llllll}\text { (11) 惟 克 果 } & \text { 斷, } & \text { 乃 周 后 艰。 } \\ \text { Wéi kè guǒ } & \text { duàn, } & \text { nǎi } & \text { wăng hòu jiān. } \\ \text { Only can quickly } & \text { make.decision, cons avoid future difficulty }\end{array}$

'If one can make a bold decision, he may avoid future difficulties.'

(The Classic of History)

Another instance of intransitive use (metaphorical) is found in 墨子 Mo Zi (490$221 \mathrm{BC})$, vol. 2:

(12) 政令

$$
\text { 不 }
$$

断則 民

民不 畏。

Zhènglìng bú duàn zé mín bú wèi.

Orders NEG stop, cONJ people NEG stand in awe

'If his orders do not stop, people would not stand in awe before him.'

(Mo Zi)

In (12), 断 duàn means 'to stop'; it is modified by the negation word 不 bú. In Mo Zi, vol. 6, 断 duàn is also found to function as a substantive intransitive verb, as in (13):

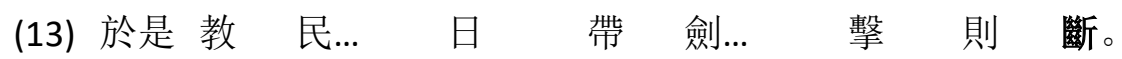
Yú shì jiāo mín ... rì dài jiàn ... jī zé duàn. cons teach people... daytime carry weapons, attack conj break '(The ancient sage-kings) taught the people to carry weapons in the daytime. When assaulted by the animal, people attack it, then the head of the animal will break.'

(Mo Zi)

断 duàn as an intransitive verb, is found 13 times in Mo Zi. Among them, nine tokens are in a substantive intransitive form, i.e. 'break (intr.)', while four tokens render a metaphorical meaning, i.e. 'stop'. Heine, Claudi and Hünnemeyer (1991) propose that the grammatical structure of the development of lexemes runs as follows: person > object $>$ activity $>$ space $>$ time $>$ quality. The metaphorical function seen in (11) and (12) suggests that the lexicalization of 断 duàn probably began as early as the Spring and Autumn period. We look for more evidence of this by looking at data in Middle Chinese and Pre-Modern Chinese.

\section{3 断 as adjective}

The following illustration is taken from 荀子 Xun Zi (Warring State: 475 BC-221 BC), where 断 duàn plays an adjective role:

(14) 周公之状, 身如斷蓄。

Zhōu gong zhī zhuàng, shēn rú duàn zī.

Zhou Duke GEN shape, body like broken dry tree

'The shape of Duke Zhou is like a broken dry tree.'

(Xun Zi) 
However, adjective use is only detected once in all Pre-Qin sources. As a result, it may not be appropriate to propose that the adjective function appears in the Warring State period. We leave this point for now and return to it in Section 4.

\section{4 断 duàn as a noun}

Apart from its transitive and intransitive characters, some noun uses are found in Old Chinese, meaning 'judgement'. (15) is an illustration from 荀子 Xun Zi.

(15) 履

Lü

天子 之 籍, 聽 天下 之 斷。

tiān zǐ zhī jí, tīng tiān xià zhī duàn.

Undertake King GEN duty, listen people GEN advice

'Undertake the duties as a king and take advice from the people.'

(Xun Zi)

In Zhuang Zi (350-250 BC), there are four tokens of noun use.
(16)
制利
天下。
Shì yǐ yī rén zhī duàn
zhì lì
tiān xià.
Be PREP one man GEN judgement rule benefit world
'In all this one man is seeking to benefit the world by his judgement and
enactments (of such a nature).'
(Zhuang Zi)

Table 2 lists types and tokens for different functions of 断 duàn in Old Chinese.

Table 2: Types and tokens of 断 duàn's functions in Old Chinese

\begin{tabular}{llcccccc}
\hline Source & Period & $\begin{array}{c}\text { Trans. } \\
\text { verb }\end{array}$ & $\begin{array}{c}\text { Intrans. } \\
\text { verb }\end{array}$ & $\begin{array}{c}\text { Result. } \\
\text { compl. }\end{array}$ & Adj. & Adv. & Noun \\
\hline 周易 Book of Changes & Western Zhou & $8(8)^{6}$ & 0 & 0 & 0 & 0 & 0 \\
詩經 Odes & Western Zhou & $2(3)$ & 0 & 0 & 0 & 0 & 0 \\
尚书 The Classic of History & Spring and Autumn & $3(3)$ & $1(1)$ & 0 & 0 & 0 & 0 \\
孫子兵法 Military Science of Sun Zi & Spring and Autumn & 0 & 0 & 0 & 0 & 0 & 0 \\
墨子 Mo Zi & Spring and Autumn - & $28(42)$ & $8(13)$ & 0 & 0 & 0 & 0 \\
& Warring Sate & & & & & & \\
論語 Analects & Spring and Autumn - & 0 & 0 & 0 & 0 & 0 & 0 \\
苟子 Xun Zi & Warring Sate & & & & & & \\
莊子 Zhuang Zi & Warring State & $7(8)$ & $10(11)$ & 0 & $1(1)$ & 0 & $1(1)$ \\
孟子 Mencius & Warring State & $3(3)$ & $3(3)$ & 0 & 0 & 0 & $4(4)$ \\
管子 Guan Zi & Warring State & $2(2)$ & $2(2)$ & 0 & 0 & 0 & 0 \\
\hline
\end{tabular}

Perhaps we can pause here and draw a preliminary conclusion: 断 duàn was initially transitive and obtained its intransitive function during the Spring and Autumn

\footnotetext{
${ }^{6}$ The number outside of the brackets, ( ), is the type and the number inside of the brackets is the token.
} 
period (772 BC-476 BC). The two functions co-existed for the rest of the Pre-Qin period. Moreover, by the Warring State period, the intransitive use seems to be employed in abundance.

Furthermore, it is assumed that in the Warring State period the transitive 断 duàn 'break' was lexicalized and developed the metaphorical meaning of 'judge'. The appearance of adjectival use is only found once in a source written in the period 475 $B C-221 \mathrm{BC}$, therefore it is not yet possible to conclude that it occurred as early as the Warring State period. However, the upcoming discussion of Middle Chinese (Section 4) might provide an answer. The adverb function is not detected in the Pre-Qin period, nor is the resultative complement use.

\section{4 断 in Pre-Middle and Middle Chinese}

Having drawn a picture of 断 duàn's evolution in Old Chinese, this section engages in an analysis of Middle Chinese data. Pre-Middle Chinese is a significant period with regard to Chinese linguistics. With the occurrence of disyllabic words (e.g. disyllabic nouns, disyllabic particles and disyllabic verbs), serial verb constructions gradually declined and verb compounds appeared.

There is an ongoing debate on whether serial verb construction (SVC) exists in Chinese. In earlier times, domestic linguists such as Lü (1958) and Ma (1961) argued that the multiple verb constructions in contemporary Chinese are not SVCs but 'complex-predicate constructions'. Lü (1979), Hu and Wen (1990), Chao (1980) welcomed the terminology 'SVC' in modifying multiple verb constructions in contemporary Chinese. Lü (1979) defines SVC as follows: V1 and V2 are carried out by the same agent; the two must be strictly successive; there could be a conjunction between V1 and V2. Yang and He (1992) discussed the relationship between V1 and V2 from a sematic point of view. They offered the following definition. 'The two verbs share the same subject. They must be assigned to the successive relation. Essentially, the two constituents are not syntactically equal, there must be a core constituent, and the other plays the role as a modifier'. This study argues that SVC started declining in Middle Chinese and totally disappeared in contemporary Chinese. The instances that SVC supporters often bring about are 跑上来 'pǎo shàng lái' (run-asend-come), 跑下 去 'păo xià qù' (run-decend-go), 走进来 'zǒu jìn lái' (walk-enter-come), 爬出去 'pá chū qù' (creep-exit-go). We do not deem them SVCs because syntactically the three constituents are not equal. Third constituents, i.e. 来, 去, are grammaticalized into deictic, merely indicting the direction.

This section first looks back to the devolvement of $\mathrm{V}-\mathrm{V}$ and then moves on to see duàn's other functions in this period. 


\subsection{A brief quest to identify the development of Chinese verb compounds}

Instances of 断 duàn following an action verb can be traced back as far as the Warring State period. The following piece of data is drawn from Xun Zi (475 BC-221 BC).

(17) 斬 斷枯磔。

Zhăn duàn kū zhé.

Cut break wither dismember

'Behead someone as a warning to others and tear a person asunder by five carts. $^{7}$

(Xun Zi)

斬㫁枯磔 zhăn duàn kū zhé indicates a punishment in ancient China. Grammaticalization of duàn has not yet started; duàn functions as a substantive intransitive verb. The combination of the two constituents, i.e. 斩 zhăn and 断 duàn, is rather loose. Their location can be reversed (see duan-zhan (18) vs. zhan-duan (19)). Four tokens of 迦斬 duàn-zhăn are found in the History of the Han dynasty (Eastern Han dynasty AD 36-111).

(18) 衣繡

Yī xiù

杖斧, 斷斬 於郡國。

zhàng fŭ, duàn-zhăn yú jùn guó.

Wear splendid clothes hold axe, break-cut DAT prefecture

'Those who wear splendid clothes and with high status are beheaded in that prefecture.'

(History of the Han dynasty)

This leads us to contend that the two constituents received equal syntactic weight, and to refer to constructions such as 斬斷枯磔 zhăn duàn kū zhé and 㒬斬 zhăn duàn as serial verb constructions (SVCs). Such data were not detected in the Spring and Autumn period, and were only found once in the Warring State period. However, this suggests that atthis time the use of verb compounds in the Chinese language was at an embryonic stage.

In Pre-Middle Chinese it is observed that the main function of duàn remained that of a verb (in the Western Han dynasty, transitive verb: $65 \%$; intransitive verb: $33 \%$. In the Eastern Han dynasty, transitive verb: $74 \%$; intransitive verb: $23 \%$ ). Below is an illustration drawn from 漢書 History of the Han dynasty, where duàn appears in a coordinate V-V.

$\begin{array}{llll}\text { (19) 殷 紂 斷棄 } & \text { 先祖 } & \text { 之 } & \text { 樂。 } \\ \text { Yin zhòu duàn-qì } & \text { xiān-zù } & \text { zhī } & \text { lè. } \\ \text { Yin Zhou cut.off-abandon } & \text { patriarch GEN } & \text { enjoyment } \\ \text { 'Yin Zhou abandoned the enjoyment that the patriarch had.' }\end{array}$

(History of the Han dynasty)

\footnotetext{
${ }^{7}$ Legal interpretation: an ancient punishment.
} 
The two constituents, i.e. V1 断 duàn 'break' and V2 棄 qì 'abandon', have the same meanings and share equal syntactic status. Similar types of verb compounds are found in Records of the Three Kingdoms (Western Jin dynasty AD 265-300), i.e. 斷絕 duàn-jué 'cut-off'.
(20)
令
周昂 盜居 其
位,
斷絕 堅糧。
Shào lìng zhōu-áng dào jū qí wèi, duàn jué jiān liáng.
Yuan-shao command Zhou-ang usurp PRON stronghold, cut-off food
'Yuan-shao commanded Zhou-ang to usurp the stronghold and to cut off the food
supply.'
(Records of the Three Kingdoms)

斷絕 duàn-jué 'cut-off' is a coordinate V-V, i.e. the two constituents are transitive and have exactly the same meaning, which is 'cut off'. There are 23 tokens of 斷絕 in Records of the Three Kingdoms. During the Tang dynasty, coordinate V-V was more common. For instance, there are three tokens of 禁斷 jìn-duàn 'forbid-break' found from the Sui dynasty period, but 25 fromthe Tang dynasty period.

Moreover, 断 duàn in coordinate $\mathrm{V}-\mathrm{Vs}$ can have the following variations:

(21) a. 斷定 duàn-dìng 'judge-assert'

Context: 劉端臨、王引之斷定正文之「鄉大夫」亦當作「卿大夫」 8

Translation: 'Liu Duanlin and Wang Yinzhi assert that [Xiang Daifu] refers to

[Qing daifu]'

b. 判斷 pàn-duàn 'judge-decide'

Context: 假設甲乙, 令其判斷 ${ }^{9}$

Translation: 'Suppose there are Part A and Part B, we let him/her judge.'

c. 斷決 duàn-jué 'pronounce-sentence'

Context: 判者, 斷決百事 ${ }^{10}$

Translation: 'The judge, is supposed to make judgement on everything.'

To note, duàn is transitive in all circumstances (19-21). However, there is a salient distinction between duàn in (21) and duàn in (19-20): 断 in (19-20) retains the substantive transitive function and semantically conserves the original meaning 'to

\footnotetext{
${ }^{8}$ Detailed explanation:

劉端臨，王引之斷定正文之「鄉大夫」亦當作卿大夫」

Liú Duānlín, Wáng Yĩnzhī duàn-dìng zhèng-wén zhī xiāng dàfū yì dāng-zuò qīng dàfū

Liú Duānlín, Wáng Yĩnzhī assert text GEN xiāng dàfū also interpreted qīng dàfū

${ }^{9}$ Detailed explanation:

假設 甲, 令 其 判斷.

jiă shè jiă yĭ, lìng qí pàn duàn

suppose Part A Part B, let him/her judge

${ }^{10}$ Detailed explanation:

判者, 斷決百事。

pàn zhě, duàn-jué bǎi shì

judge, make judgement everything
} 
break'. On the other hand, duàn in (21) behaves as a transitive verb at the syntactic level but renders a different semantic properties. We thus assume such duàn is lexicalized and conveys a metaphorical meaning, i.e. 'judge'. This suggests that it is the transitive function that is subject to lexicalization.

\section{2 断 duàn as a resultative complement}

Having briefly touched upon the development of verb compounds, the following sections focus on how 断 duàn developed into a resultative complement. As confirmed in a search of the Pre-Middle Chinese database, by the time of 史記 The Historical Record (the Western Han dynasty 109-91 BC), 断 duàn was not yet a resultative complement. It was in 漢書 History of the Han dynasty (AD 36-111) that duàn was first found to function as such.

(22)

$\begin{array}{llllll}\text { 亡 } & \text { 非 } & \text { 同類, } & \text { 割斷 } & \text { 歷 } & \text { 久。 } \\ \text { Wáng } & \text { fēi } & \text { tong-lèi, } & \text { gē-duàn } & \text { lì } & \text { jiǔ. } \\ \text { the dead } & \text { NEG } & \text { same kind, } & \text { cut-broken } & \text { history } & \text { long }\end{array}$

'The dead are not the same kind as us; the relation has been cut off for a long time.'

(History of the Han dynasty)

In the compound 割斷 gē-duàn 'cut-down', V1 割 gē 'cut' denotes an action and V2 contributes to the result of the action, i.e. 'broken'. A verb weakening is seen in the constituent duàn. The lexical conceptual structure of (22) is as follows:

(23) $[x$ ACT ON $y]$ CAUSE $[y$ BECOME $[y$ BE AT-z] ] 割 $g e^{-}$'cut' 斷 duàn 'broken'

This inspires us to see duàn as a resultative complement and to further deduce that duàn started being grammaticalized in Eastern Han dynasty. Crucially, it is the grammaticalization that turned the intransitive use into the resultative complement. In fact, apart from change-of-state verbs, motion verbs have also revived grammaticalization. Intransitive motion verbs were grammaticalized and turned into directional complement. For instance, 入 rù 'enter' originated with both transitive and intransitive uses, as shown by data from Odes. The grammaticalization of $入$ into a directional complement started in Western Han and continued during the Southern \& Northern dynasties. The directional complement 入 rù 'enter' may build a predicatecomplement V-V with several manners of motion verbs, such as 走 zǒu 'walk' (走入 zǒu rù 'walk-into': 145 tokens). Intriguingly, the combination of [manner of motion $\mathrm{V}+$ directional complement] can be rather productive, i.e. the manner verb may form predicate-complement V-Vs with a number of directional complements, such as 出 chū 'exit' (c.f. 走出 zǒu chū 'walk-exit') for example. On the other hand, directional complements may also form a number of predicate-complement $\mathrm{V}-\mathrm{Vs}$ in combination with any manner verb. For instance, 跑 păo 'run', cf. 跑出 păo chū 'run-out'. 
The following data provide another illustration of a case where duàn plays the role of a complement:
(24)
已 捕 斬
斬斷 信 二子
縠鄉侯章,
德廣侯鮁。
Yí bǔ zhăn duàn xìn èr zǐ yù xiāng hóu zhāng, dé guăng hóu wěi
ADV arrest behead broken Xin 2 sons Yuxianghouyhang Deguanghouwei
'Have arrested and beheaded Xin's two sons, Yuxianghouzhang and
Deguanghouwei.'
(History of the Han dynasty)

The first two constituents, i.e. 捕 bǔ 'arrest' and 斬 zhăn 'behead', are in a successive relation, and convey action while 斷 duàn renders the result 'broken'. Morphologically, the first two constituents carry equal weigh and the third constituent, 斷 duàn, renders the result of an action. In another work from the Eastern Han dynasty period, i.e. 釋名 The Book of Title Explanation (AD 19-210), 断 duàn is found playing the complement role in V-V 斬㫁 zhăn-duàn:

(25) 斧 以 斬斷, 見 者 皆 感懼
Fǔ yǐ zòn
Axe post cut-broken, see PRON all frightened EXCL

'Beheaded by axe. Everyone saw the execution. They were all frightened.'

(The Book of Title Explanation)

Note that the semantic role of the particle 以 yr here is that of a tool: it appears after the noun and forms a postpositional phrase '斧以 fǔ y̌̌ N+POST', which in contemporary Chinese would be prepositional phrase '以斧 yĭ fŭ PREP + N (by axe)'. Moreover, 感懼 qì-jù is a coordinate intransitive V-V, meaning 'be frightened of'.

In 後漢書 Book of the Later Han (AD 420-445), two tokens of 断 duàn are found functioning as a resultative complement in 斬㝴 zhăn duàn:

(26) 埶 足斬 斷。

Zhí zú zhăn duàn.

twine feet cut break

'His twine feet were chopped off.'

(Book of the Later Han)

During the Western Jin dynasty (AD 266-316), duàn's function as a resultative complement became very productive. An illustration is given in (27):

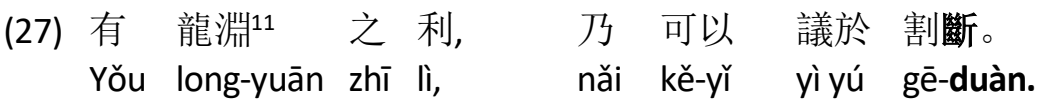
Have Long-Yuan gen keenness, cons be able to sever-broken 'It seems to be as keen as the Long-Yuan sword and therefore capable of cutting down everything.'

(Records of the Three Kingdoms)

11 龍淵 long-yu ān 'Long Yuan' refers to a famous sword made in the Spring and Autumn period. 
Only two tokens of a resultative complement use are detected in the database of Pre-Middle Chinese. The chief function of duàn remains verbal, of which 135 tokens represent a transitive verb and 51 tokens an intransitive verb. In Middle Chinese, the use of the resultative complement increased, i.e. 54 tokens are detected. This suggests that duàn's transition to a resultative complement began in Pre-Middle Chinese, specifically during the Eastern Han dynasty. Essentially, it is in regard to the intransitive function of duàn that grammaticalization took place. Figure 2 summarises the grammaticalization path during Middle Chinese:

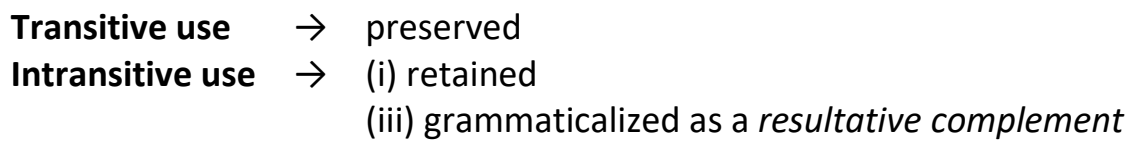

Figure 2: The grammaticalization path of the Chinese verb 断

\section{3 断 duàn as a noun}

Recall that in Pre-Qin works, i.e. Xun Zi, Guan Zi and Zhuang Zi, six tokens of duàn being used as a noun were detected. It was during the Western Han dynasty that duàn started to function as a noun. The transition continues in Middle Chinese. There are 14 tokens in Records of the Three Kingdoms (Western Jin dynasty: AD 265-300); 40 tokens in Tong Dian (Tang dynasty AD 801); 11 tokens in The Analects of Four Confucian Classics (Southern Song dynasty AD 1150-1200). Below is an illustration from Records of the Three Kingdoms:
(28)

袁術 勇 而 無 斷。
Yuán-shù yǒng ér wú duàn.
Yuan Shu brave cons lack decisiveness
'Yuan Shu is brave but lacks decisiveness.'

(Records of the Three Kingdoms)

The following is taken from 四書章句集注 The Analects of Four Confucian Classics, where 断 duàn is found in a compound noun 間衒 jiān-duàn, meaning 'interruption'. Six tokens of 間斷 jiàn-duàn is found in The Analects of Four Confucian Classics.

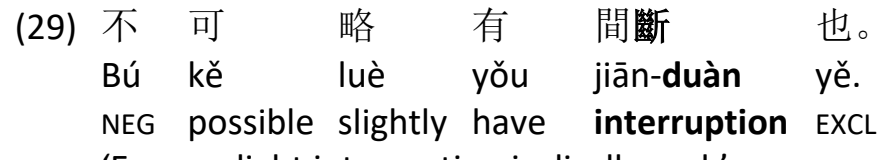

'Even a slight interruption is disallowed.'

(The Analects of Four Confucian Classics)

In fact, duàn as an individual morpheme and functioning as noun is mostly seen in Old Chinese and Middle Chinese. In its function as a noun it appears rather rarely in Contemporary Chinese. In the Modern Chinese (http://ccl.pku.edu.cn/) corpus, 300 
tokens of individual duàn were detected, however, not a token is found behaving as a noun.

\section{4 断 duàn as an adverb}

The adverbial function of 断 duàn is not detected until Middle Chinese. Its first appearance was found in 容斋三笔 The Three Writings in RongZhai (Southern Song dynasty: AD 1123-1202) in the form of a compound adverb, 断然 duan-ran 'absolutely'. An illustration is provided in (30):

(30) 后汉

Hòu-hàn
中 所 载 zhōng suǒ zăi

Book of the Later Han inside PART 断然13 如 出 两手。 duàn-rán rú chū liăng shǒu absolutely like from two source 'The papers in the Book of the Later Han are entirely different from those (in the Book of Han).'
(The Three Writings in Rong Zhai)

In Tong Dian (Tang dynasty 801) duàn as an adverb is often found combined with a modal auxiliary 可 'could'. They together render the meaning of 'definitely could'.

$\begin{array}{llllll}\text { 以 此 徵 } & \text { 之, 斷 } & \text { 可 } & \text { 識 } & \text { 矣。 } \\ \text { Yì cǐ zhēng zhī, duàn } & \text { kě } & \text { shí } & \text { y̌̃. } \\ \text { Use this detect PRON, absolutely could } & \text { recognize } & \text { EXCL } \\ \text { 'From this, we shall absolutely recognise it.' } & & \end{array}$

(Tong Dian)

There are nine tokens of the adverbial use in Tong Dian and one in The Analects of Four Confucian Classics. It seems that the duàn's adverbial function was not very productive in the Middle Chinese period. In fact, it is in Pre-Modern Chinese, specifically during the Qing dynasty, that duàn was mostly employed as an adverb. Section 5 will delve into this in detail.

\section{5 断 duàn as an adjective}

The following data present a further aspect, illustrating cases of 断 duàn being employed as an adjective:

\footnotetext{
12 固 gù refers to 班固 Bān Gù, a historian during the Eastern Han Dynasty.

${ }^{13}$ Here 斷然 duànrán together forms an adverb. 然 rán functions as a suffix in this sentence, indicating the state. 然 rán originally is a pronoun, meaning 'this'. It is a result of grammaticalization, which took place in Early Middle Chinese. Other illustrations of this use are: 猝然 cù-rán 'suddenly', 陡然 dǒu-rán 'unexpectedly', 猛然 měng-rán 'abruptly', 骤然 zhòu-rán 'suddenly'.
} 
(32) 腸皆 寸寸 ${ }^{14}$ 斷。

$\begin{array}{lll}\text { Cháng jiē } & \text { cùn cùn } & \text { duàn. } \\ \text { Intestines all } & \text { very short } & \text { broken }\end{array}$

'The intestines are all broken.'

(A New Account of the Tales of the World: AD 420-581)

(33) 以 剛斷稱。

Yĩ gang duàn chēng

PREP manful decisive known

'Be known as tough and decisive.'

(Records of the Three Kingdoms)

Nine tokens were found in Records of the Three Kingdoms, 12 tokens in Tong Dian, and six tokens in The Analects of Four Confucian Classics. Table 3 summarises the types and tokens of the various functions of duàn in Pre-Middle and Middle Chinese.

Table 3: The type and (token) of duàn's various functions in Pre-Middle and Middle Chinese

\begin{tabular}{|c|c|c|c|c|c|c|c|}
\hline Source & Period & Tran. verb & $\begin{array}{l}\text { Intran. } \\
\text { verb }\end{array}$ & $\begin{array}{l}\text { Result. } \\
\text { compl. }\end{array}$ & Adj. & Adv. & Noun \\
\hline 史記 The Historical Records & Western Han & $38(43)$ & $10(22)$ & 0 & 0 & 0 & $1(1)$ \\
\hline 漢書 History of the Han dynasty & Eastern Han & $63(92)$ & $13(29)$ & $2(2)$ & 0 & 0 & $1(1)$ \\
\hline $\begin{array}{l}\text { 世說新語 A New Account of the } \\
\text { Tales of the World }\end{array}$ & $\begin{array}{l}\text { Southern and } \\
\text { Northern dynasties }\end{array}$ & $8(8)$ & $4(5)$ & $2(2)$ & $1(1)$ & 0 & $1(1)$ \\
\hline $\begin{array}{l}\text { 三國志 Records of the Three } \\
\text { Kingdoms }\end{array}$ & Western Jin & 78 (110) & $14(33)$ & $16(20)$ & $6(9)$ & 0 & $8(14)$ \\
\hline 通典 Tong dian & Tang & $122(213)$ & 89 (149) & $7(31)$ & $8(12)$ & $7(9)$ & $19(40)$ \\
\hline $\begin{array}{l}\text { 四書章句集注 The Analects of four } \\
\text { Confucian Classics }\end{array}$ & Southern Song & $8(10)$ & $6(9)$ & $1(1)$ & $5(6)$ & $1(1)$ & $6(11)$ \\
\hline
\end{tabular}

\section{Pre-Modern Chinese}

Pre-Modern Chinese period is the time when the resultative complement, noun, adjective, adverb significantly developed. 红楼梦 Dream of Red Mansions is a long novel, completed during the Qing dynasty (AD 1350-1400). Among the 145 断 duàn tokens in the novel, transitive use is found 17 types, 24 tokens; and the intransitive use is 14 types, 16 tokens. The following sections particularly address duàn's functions of resultative complement, noun, adjective and adverb.

\section{1 断 duàn as a resultative complement}

断 duàn's function as a resultative complement in this period is productive. There are 47 tokens found in 三國演義 Romance of the Three Kingdoms (Ming dynasty AD 1780-

14 寸: $1 / 3$ decimetre. It used to describe the degree of brokenness. 
1792). On the other hand, there are only 14 tokens found in 红楼梦 Dream of the Red Chamber, a novel completed in Qing dynasty. A typical example is provided in (34):

(34)

$\begin{array}{llll}\text { 一 戟 } & \text { 砍斷 安國 手腕。 } \\ \text { Yi jǐn } & \text { kăn-duàn ān-guó shǒu-wàn. } \\ \text { One halberd } & \text { cut-down } & \text { An-Guo wrist } \\ \text { 'Cut down the wrist of General An Guo with one halberd.' }\end{array}$

(Romance of the Three Kingdoms)

Apart from the above verbs, the database further reveals 断 duàn's forming V-Vs with the following action verbs: 射斷 shè-duàn 'shoot-broken', 剖斷 pōu-duàn 'dissectbroken', 截斷 jié-duàn 'sever-broken'; 拗斷 niù-duàn 'bend-broken', 絕斷 jué-duàn 'sever-broken'; 遮斷 zhē-duàn 'intercept-broken', 燒斷 shāo-duàn 'burn-broken', 塞 斷 sè-duàn 'stuff-broken', 拆斷 chāi-duàn 'dismantle-broken', 隔斷 gé-duàn 'separatebroken'. These V-Vs have the following features:

First, they may be transitive or intransitive, e.g. (35).

(35) a. 拆断 as transitive V-V

待我引張任 過橋, 你便將 橋 拆斷。

Dài wǒ yǐn zhāng-rèn guò qiáo, nǐ biàn jiāng qiáo chāi-duàn. after I guide Zhangren cross bridge, you then AUX bridge dismantle-broken 'After I guide Zhang Ren across the bridge, please dismantle the bridge.'

\section{b. 拆斷 as intransitive V-V}

$\begin{array}{lllllll}\text { 急 回 } & \text { 軍 } & \text { 時, 橋 } & \text { 己 } & \text { 拆斷 } & \text { 了。 } \\ \text { Jí huí jūn shí, qiáo } & \text { yí } & \text { chāi-duàn } & \text { le. }\end{array}$

Hurry return army time, bridge already dismantle-broken PERF

'When I hurried back to the army, I found the bridge already dismantled.'

(Romance of the Three Kingdoms)

Second, they are very productive and can be subcategorised into the cause-effect syntactic V-V. As we can see from the above instances, V1s denote the cause and are conveyed by an agentive verb, e.g. jie 'sever', shao 'burn'. V2s contribute to the change of state and entail an endpoint of a change-of-state event, and would, in the light of scalar structure (c.f. Kennedy and McNally 2005), be regarded as closed-scale morphemes. As a result, this study considers $\mathrm{V} 2$ to be the head of this type of $\mathrm{V}-\mathrm{V}$. A thorough analysis of the development of Chinese verb compounds seems necessary. However, in this paper, this issue will not be pursued any further. We leave this for future study.

\section{2 断 duàn as a noun}

In the database, there are 12 tokens found in Romance of the Three Kingdoms (AD 1350-1400) and four in Dream of Red Mansions (AD 1780-1792). Typical examples are (36) and (37): 
$\begin{array}{llllllll}\text { (36) 袁紹 好 } & \text { 謀 } & \text { 無 } & \text { 斷, } & \text { 不 足 } & \text { 為 慮。 } \\ \text { Yuán-Shào hào } & \text { móu } & \text { wú duàn, } & \text { bú zú } & \text { wéi lü. }\end{array}$

Yuan Shao fond of strategy lack decisiveness, NEG deserve PERP worry

'Yuan Shao is good at planning but can not make decisions, therefore he is not to

be worried about.'

(Romance of the Three Kingdoms)

(37) 以十尺為斷。

Yĩ shí chĩ wéi duàn.

post ten feet as measure

'Make ten feet as a measure.' (Annotation on Mo-tse)

\section{3 断 duàn as an adverb}

In Romance of the Three Kingdoms, three tokens of adverb use were detected.

$\begin{array}{lllll}\text { (38) 三者 } & \text { 缺一, 斷 } & \text { 不 } & \text { 肯 } & \text { 降。 } \\ \text { Sān zhě } & \text { quē yī, duàn } & \text { bú } & \text { kěn jiàng. } \\ \text { Three conditions lack one, absolutely } & \text { NEG } & \text { agree } & \text { capitulate } \\ \text { '(They) won't capitulate unless the three demands are met.' }\end{array}$

(Romance of the Three Kingdoms)

In Dream of Red Mansions 74 tokens of an adverbial use were found. (39) is an illustration:

(39) 因叫我回大爺, 今日斷不能來了。 Yin jiào wǒ huí dà-yé, jīn-rì duàn bú néng lái le. CONJ ask me reply lord, today definitely NEG AUX come EXCL '(He) asked me to reply to the lord that today he is definitely unable to come over.'

Duàn here modifies the negative modal auxiliary 不能 bú-néng 'can not' meaning 'definitely'. We also observed that by the time of the Qing dynasty (AD 1644-1912), disyllabic roots (e.g. 大爺 dà-yé 'lord', 今日 jinn-rì 'today') seem to have entirely replaced the monosyllabic word roots that were used around 1200 BC.

\section{4 断 duàn as an adjective}

Adjective use was detected for 12 types (13 tokens) in Dream of Red Mansions, as exemplified by (40):

$\begin{array}{lllllll}\text { (40) 你 看 這 斷紋, } & \text { 不 } & \text { 是 牛族 似 } & \text { 的 麼? } \\ \text { Nì kàn zhè duàn-wén, bú shì niú-máo sì } & \text { de me. } \\ \text { You look at this broken-line, NEG COP yak resemble } & \text { PART EXCL }\end{array}$

'Look at these lines, don't they resemble the yaks?' 
Duàn modifies the noun 紋 wén 'line'. The relative marker 的 de may be added after duàn, i.e. 断的紋 duàn-de-wén 'the broken line'.

The foregoing discussion is based upon the findings provided in Table 4.

Table 4: The type and (token) of 断's various functions in Pre-Modern Chinese

\begin{tabular}{|c|c|c|c|c|c|c|c|}
\hline Source & Period & $\begin{array}{l}\text { Trans. } \\
\text { verb }\end{array}$ & Intrans. verb & $\begin{array}{l}\text { Result. } \\
\text { compl. }\end{array}$ & Adj. & Adv. & Noun \\
\hline $\begin{array}{l}\text { 三國演義 Romance of the Three } \\
\text { Kingdoms }\end{array}$ & Ming dynasty & $10(70)$ & $19(79)$ & $24(47)$ & 0 & $3(3)$ & $8(12)$ \\
\hline $\begin{array}{l}\text { 红楼梦 } \\
\text { Dream of Red Mansions }\end{array}$ & Qing dynasty & $17(24)$ & $14(16)$ & $9(14)$ & $12(13)$ & $22(74)$ & $2(4)$ \\
\hline
\end{tabular}

Table 5 presents the percentage of each function of duàn from Old Chinese to PreMiddle and Middle Chinese.

Table 5: The percentage of each function of duàn from Old Chinese to Pre-Middle and Middle Chinese

\begin{tabular}{lccccccc}
\hline Period & $\begin{array}{c}\text { Tran. } \\
\text { verb }\end{array}$ & $\begin{array}{c}\text { Intran. } \\
\text { verb }\end{array}$ & $\begin{array}{c}\text { Result. } \\
\text { compl. }\end{array}$ & Adj. & Adv. & Noun & $\begin{array}{c}\text { Total } \\
\text { (token) }\end{array}$ \\
\hline Western Zhou & $100 \%$ & 0 & 0 & 0 & 0 & 0 & 11 \\
Spring and Autumn - Warring State & $56 \%$ & $38 \%$ & 0 & $1 \%$ & 0 & $5 \%$ & 130 \\
Western Han & $65 \%$ & $33 \%$ & 0 & 0 & 0 & $2 \%$ & 66 \\
Eastern Han & $74 \%$ & $23 \%$ & $2 \%$ & 0 & 0 & $1 \%$ & 124 \\
Southern and Northern dynasties & $47 \%$ & $29 \%$ & $12 \%$ & $6 \%$ & 0 & $6 \%$ & 17 \\
Western Jin & $59 \%$ & $18 \%$ & $11 \%$ & $5 \%$ & 0 & $8 \%$ & 186 \\
Tang & $47 \%$ & $33 \%$ & $7 \%$ & $2 \%$ & $2 \%$ & $9 \%$ & 454 \\
Southern Song & $26 \%$ & $23 \%$ & $3 \%$ & $16 \%$ & $3 \%$ & $29 \%$ & 38 \\
Ming dynasty & $33 \%$ & $37 \%$ & $22 \%$ & 0 & $1 \%$ & $6 \%$ & 211 \\
Qing dynasty & $16 \%$ & $11 \%$ & $10 \%$ & $9 \%$ & $51 \%$ & $3 \%$ & 145 \\
\hline
\end{tabular}

At the stage of Pre-Modern Chinese, duàn has grown into a polysemous lexeme, combining transitive, intransitive, resultative complement, adjectival, adverbial, and nominal function together. We may contend that the rudiment duàn in contemporary Chinese was shaped during the Pre-Modern Chinese period.

\section{Conclusion}

This paper discussed the evolution of the Chinese verb duàn, exploring how it transformed from being a substantive transitive verb to the verb of various functions in contemporary Chinese (i.e. a resultative complement, an adjective and an adverb). Findings reveal that duàn was initially transitive and took on its intransitive function during the Spring and Autumn period (772-476 BC). The two functions co-existed for the rest of the Pre-Qin period and they remained so in Middle Chinese. Duàn's 
transition into a resultative complement began during the Eastern Han dynasty and became productive in Middle Chinese. Duàn developed functioning as a noun in the Warring State period, while its adjectival and adverbial functions began in Middle Chinese.

Although some transitions took place during overlapping periods, they developed via two separate paths: the process by which the intransitive verb duàn developed into a resultative complement, an adverb, and an adjective was grammaticalization; the process by which duàn developed into a noun was a case of lexicalization. Essentially, it was the intransitive function that became the subject to grammaticalization; it was the transitive function that was subject to lexicalization. Table 6 presents a summary of the two evolutions. Path A indicates the trajectory of grammaticalization and Path B denotes the trajectory of lexicalization.

Table 6: Stages of development for duàn

\begin{tabular}{|c|c|c|c|}
\hline & Timetable & $\begin{array}{c}\text { Path A } \\
\text { Lexicalization }\end{array}$ & $\begin{array}{c}\text { Path B } \\
\text { Grammaticalization }\end{array}$ \\
\hline i & Western Zhou & Transitive use & \\
\hline ii & Spring and Autumn & & Intransitive use \\
\hline iii & Warring State & $\begin{array}{l}\text { semantic change: } \\
\text { lexicalized, meaning 'judge' }\end{array}$ & \\
\hline iv & Western Han & $\begin{array}{l}\text { syntactic change: } \\
\text { lexicalized as a noun } \\
\text { (judgement) }\end{array}$ & \\
\hline v & $\begin{array}{l}\text { Eastern Han and } \\
\text { Southern and Northern } \\
\text { dynasties }\end{array}$ & & $\begin{array}{l}\text { syntactic change: } \\
\text { grammaticalized as a } \\
\text { resultative complement }\end{array}$ \\
\hline vi & Southern Song dynasty & & $\begin{array}{c}\text { syntactic change: } \\
\text { grammaticalized as an } \\
\text { adverb }\end{array}$ \\
\hline vii & Middle Chinese & & $\begin{array}{c}\text { syntactic change: } \\
\text { grammaticalized as an } \\
\text { adjective }\end{array}$ \\
\hline
\end{tabular}

A proposal to treat the diachronic change as a cline is put forward as follows: (a) grammaticalization and lexicalization are not distinct processes but rather happen to a lexeme at the same point; and (b) the interrelationship of the two processes is orthogonal. 


\section{References}

Bisang, W. (1992). Das Verb im Chinesischen, Hmong, Vietnamesischen, Thai und Khmer. Tübingen: Narr.

Bopp, F. (1816). Über das Conjugationssystem der Sanskritsprache in Vergleichung mit jenem der griechischen, lateinischen, persischen und germanischen Sprache. Hildesheim: Olms (reprint of the 1816 edn, Frankfurt/Main: Andreäische).

Bopp, F. (1833). Vergleichende Grammatik des Sanskrit, Zend, Griechischen, Lateinischen, Litauischen, Gotischen und Deutschen, vol. 1. Berlin: Dümmler.

Brinton, L., \& Traugott, E. (2005). Lexicalization and Language Change: Research Surveys in Linguistics, Cambridge: Cambridge University Press.

Bybee, J., Perkins, R., \& Pagliuca, W. (1994). The evolution of grammar: Tense, aspect and modality in the languages of the world. Chicago: University of Chicago Press.

Chao, Y. (1948). Mandarin primer: An intensive course in spoken Chinese. Cambridge, MA: Harvard.

Chao, Y. (1968). A Grammar of Spoken Chinese. Berkeley: University of California Press.

Croft, W. (1990). A conceptual framework for grammatical categories (or: a taxonomy of Propositional Acts). Journal of Semantics 7(3), 245-279.

Croft, W. (2000). Explaining Language Change: An Evolutionary Approach. Harlow, Essex, UK: Pearson Education.

Diessel, H. (2011). Grammaticalization and language acquisition. In H. Narrog \& B. Heine (Eds.), The Oxford Handbook of Grammaticalization (pp. 130-141). Oxford: Oxford University Press.

Giacalone Ramat, A. (1998). Testing the boundaries of grammaticalization. In A. Giacalone Ramat \& P. Hopper (Eds.), The Limits of grammaticalization. Amsterdam: Benjamins, 107-27.

Gisborne, N., \& Patten, A. (2011). Construction grammar and grammaticalization. In H. Narrog \& B. Heine (Eds.), The Oxford Handbook of Grammaticalization (pp. 92-104). Oxford: Oxford University Press.

Givón, T. (1971). Historical syntax and synchronic morphology. Chicago Linguistic Society Proceedings 7, 394-415.

Givón, T. (1979). On Understanding Grammar. New York: Academic Press.

Harder, P., \& Boye, K. (2011). Grammaticalization and functional linguistics. In H. Narrog \& B. Heine (Eds.), The Oxford Handbook of Grammaticalization (pp. 56-68). Oxford: Oxford University Press.

Heine, B. (1993). Auxiliaries: Cognitive Forces and Grammaticalization. Oxford: Oxford University Press.

Heine, B., \& Kuteva, T. (2007). The Genesis of Grammar: A Reconstruction. Oxford: Oxford University Press.

Heine, B., Claudi, U., \& Hünnemeyer, F. (1991). Grammaticalization: a Conceptual Framework. Chicago: University of Chicago Press.

Himmelmann, N. P. (2004). Lexicalization and grammaticalization: Opposite or orthogonal? In W. Bisang, N. P. Himmelmann \& B. Wiemer (Eds.), What makes Grammaticalization? A Look from its Fringes and its Components (pp. 19-40). Berlin: Mouton de Gruyter. 
Hopper, P., \& Traugott, E. C. (1993/2003). Grammaticalization. Cambridge: Cambridge University Press.

Hu, F., \& Wen, L. (1990). Xiandai Hanyu yufa tansuo 现代汉语语法探索. [Contemporary Chinese Grammar]. Beijing: The Commercial Press.

Karlgren, B. (1918). A mandarin phonetic reader in the Pekinese dialect. Stockholm: P.A. Norstedt och Söner.

Karlgren, B. (1949). The Chinese language. New York: Ronald Press.

Kennedy, C., \& McNally, L. (2005). Scale structure, degree modification, and the semantics of gradable predicates. Language $81,345-381$.

Kuryłowicz, J. (1965). The evolution of grammatical categories. Diogenes 51, 55-71. Reprint: Kuryłowicz, J. (1975), Esquisses linguisique II. München: W. Fink.

Langacker, R. W. (1987). Foundations of Cognitive Grammar, vol. 1: Theoretical Prerequisites. Stanford, CA: Stanford University Press.

Langacker, R. W. (1991). Foundations of Cognitive Grammar, vol. 2: Descriptive Application. Stanford, CA: Stanford University Press.

Langacker, R. W. (2011) Grammaticalization and Cognitive Grammar. In H. Narrog \& B. Heine (Eds.), The Oxford Handbook of Grammaticalization, 79-91. Oxford: Oxford University Press.

Lehmann, C. (1992). Word order change by grammaticalization. In M. Gerritsen \& D. Stein (Eds.), Internal and external factors in syntactic change. A selection of papers presented at the International Conference on Historical Linguistics (pp. 395-416). Berlin: Mouton De Gruyter.

Lehmann, C. (1995/1982). Thoughts on Grammaticalization. Munich: LINCOM EUROPA (originally published as Thoughts on Grammaticalization: A Programmatic Sketch, Vol. 1. University of Cologne: Arbeiten des Kölner Universalienprojekts 49).

Lightfoot, D. (2011). Grammaticalization and Lexicalization. In H. Narrog \& B. Heine (Eds.), The Oxford Handbook of Grammaticalization (pp. 438-449). Oxford: Oxford University Press.

Lü, J. (1958). Fuza weiyu 复杂谓语[Complex predicates]. New Knowledge Publications.

Lü, S. (1979). Hanyu yufa fenxi wenti 汉语语法分析问题 [Analysis of Chinese Grammar]. Beijing: The Commercial Press.

Ma, J. (1898/1925). Mashi Wentong 馬氏文通 [Ma's grammar]. Shanghai: Shangwu yinshuguan.

Ma, Z. (1983). Gudai Hanyu yufa 古代汉语语法 [Old Chinese Grammar]. Shangdong Education Publications.

Maspéro, H. (1934). La langue chinoise. Conferences de l'Institut de linguistique de l'Universite de Paris, Annie 1933. In Boivin \& Cie (Eds.), Paris: Ancienne librairie fume.

Nevalainen, T., \& Palander-Collin, M. (2011). Grammaticalization and sociolinguistics. In H. Narrog \& B. Heine (Eds.), The Oxford Handbook of Grammaticalization (pp. 118-129). Oxford: Oxford University Press.

Newmeyer, F. J. (1998). Language Form and Language Function. Cambrige MA: MIT Press.

Norde, M. (2001). Deflexion as a counterdirectional factor in grammatical change. Language Sciences 23(2-3), 231-264.

Packard, J.(2000). The Morphology of Chinese. New York: Cambridge University Press.

Sagart, L. (1999). The Roots of Old Chinese. John Benjamins. 
Traugott, E. C. (2002). From etymology to historical pragmatics. In D. Minkova \& R. Stockwell (Eds.), Studying the History of the English Language: Millennial Perspectives (pp. 19-49). Berlin: Monton de Gruyter.

Traugott, E. C. (2011). Pragmatics and language change. In K. Allan \& K. Jaszczolt (Eds.), The Cambridge Handbook of Pragmatics (pp. 549-565). Cambridge: Cambridge University Press.

Traugott, E. C., \& Dasher, R. B. (2002). Regularity in Semantic Change. Cambridge: Cambridge University Press.

Traugott, E. C., \& Heine, B. (1991). Approaches to Grammaticalization. Amsterdam/ Philadelphia: John Benjamins Publishing Company.

Trousdale, G. (2008). Constructions in grammaticalization and lexicalization: evidence from the history of a composite predicate construction in the history of English. In G. Trousdale \& N. Gisborne (Eds.), Constructional approaches to English grammar, Topics in English Linguistics 57 (pp. 33-67). Berlin/New York: Mouton de Gruyter.

Van Der Auwera, J. (1999). Dutch verbal prefixes: meaning and form, grammaticalization and lexicalization. In L. Mereu (Ed.), Boundaries of Morphology and Syntax (pp. 121-136). Amsterdam: Benjamins.

Wang, L. (1957/1958). Hanyu shigao 汉语史稿 [The History of Chinese language]. 3 vols. Beijing: Kexue yuan.

Yang, B., \& He, L. (1992). Gudai Hanyu yufa ji qi fazhan 古语汉语语法及其发展 [A Grammar of Ancient Chinese and Its Development]. Yuwen Publications.

Zhao, Y. (1980). Yuyan wenti 语言问题 [Issues on the Chinese language]. Beijing: The Commercial Press.

Zhu, D. (1982). Yufa jiangyi 语法讲义 [Lectures on Grammar]. Beijing: The Commercial Press.

\section{Corpus for Old Chinese, Middle Chinese and Pre-Modern Chinese}

Sturgeon, D. (n.d.). Chinese Text Project. Retrieved from https://ctext.org/

\begin{tabular}{lllr}
\hline \multicolumn{2}{l}{ Old Chinese (The texts are listed according in chronological order) } & approx. word count \\
\hline 周易 & The Book of Change & 1046-771 BC, Western Zhou & 5,000 \\
詩經 & Odes & $1046-771$ BC, Western Zhou & 39,234 \\
尚書 & The Classic of History & $772-476$ BC, Spring and Autumn & 25,700 \\
孫子兵法 & Military Science of Sun Zi & $515-512$ BC, Spring and Autumn & 6,111 \\
論語 & Analects & $480-350$ BC, Spring and Autumn - Warring State & 11,705 \\
墨子 & Mo Zi & $490-221$ BC, Spring and Autumn - Warring State & 76,516 \\
荀子 & Xun Zi & $475-221$ BC, Warring State & 90,800 \\
莊子 & Zhuang Zi & 350-250 BC, Warring State & 65,000 \\
孟子 & Mencius & 340-250 BC, Warring State & 34,685 \\
管子 & Guan Zi & 475 BC-AD 220, Warring State - Han Dynasty & 117,000 \\
\hline
\end{tabular}




\begin{tabular}{|c|c|c|c|}
\hline \multicolumn{4}{|c|}{ Pre-Middle and Middle Chinese } \\
\hline 史記 & The Historical Records & 109-91 BC, Western Han Dynasty & 526,500 \\
\hline 漢書 & History of the Han Dynasty & AD 36-111, Eastern Han Dynasty & 742,298 \\
\hline 釋名 & $\begin{array}{l}\text { The Book of Title } \\
\text { Explanation }\end{array}$ & AD 190-210, Eastern Han Dynasty & \\
\hline 三國志 & $\begin{array}{l}\text { Records of the Three } \\
\text { Kingdoms }\end{array}$ & AD 265-300, Western Jin Dynasty & 377,803 \\
\hline 後漢書 & Book of the Later Han & AD 420-445, Southern and Northern Dynasties & 894,020 \\
\hline 世說新語 & $\begin{array}{l}\text { A New Account of the Tales } \\
\text { of the World }\end{array}$ & AD 420-581, Southern and Northern Dynasties & 79,000 \\
\hline 通典 & Tong dian & AD 801, Tang Dynasty & $3,218,000$ \\
\hline 容斋三笔 & $\begin{array}{l}\text { The Three Writings in } \\
\text { RongZhai }\end{array}$ & AD 1123-1202, Southern Song Dynasty & $1,428,000$ \\
\hline $\begin{array}{l}\text { 四書章句 } \\
\text { 集注 }\end{array}$ & $\begin{array}{l}\text { The Analects of four } \\
\text { Confucian Classics }\end{array}$ & AD 1150-1200, Southern Song Dynasty & 280,418 \\
\hline \multicolumn{4}{|c|}{ Pre-Modern Chinese } \\
\hline 三國演義 & $\begin{array}{l}\text { Romance of the Three } \\
\text { Kingdoms }\end{array}$ & AD 1350-1400, Ming Dynasty & 590,000 \\
\hline 红楼梦 & Dream of Red Chambers & AD 1780-1792, Qing Dynasty & 730,000 \\
\hline
\end{tabular}

\section{Abbreviations}

$\begin{array}{ll}\text { ADV } & \text { adverb } \\ \text { AUX } & \text { auxiliary } \\ \text { CONJ } & \text { conjunction } \\ \text { COP } & \text { copula } \\ \text { DAT } & \text { dative } \\ \text { EXCL } & \text { exclamation } \\ \text { GEN } & \text { genitive } \\ \text { NEG } & \text { negative } \\ \text { PART } & \text { particle } \\ \text { PREP } & \text { preposition } \\ \text { PRON } & \text { pronoun } \\ \text { SUF } & \text { suffix }\end{array}$

\section{Acknowledgments}

This paper is based on work that was supported by the National Foundation of Social Sciences (15CYY002) as well as the Humanities and Social Sciences Research Programme of Zhejiang University to Wenchao Li. 